\title{
Jarosław Kłaczkow, KościółEwangelicko-Augsburskiw Polsce w latach 1918-1939, Wydawnictwo Naukowe Uniwersytetu Mikołaja Kopernika, Toruń 2017, pp. 295
}

Although Catholicism was the dominant religion in interwar Poland, the religious structure of the society was a conglomerate of various denominations, which sometimes influenced economic or social and political life. This mainly applies to the Jewish minority, however, in the Second Polish Republic, there were over million followers of the Evangelical Church, although the majority of the members of this religious community were representatives of the German minority. Jarosław Kłaczkow, a historian associated with the Nicolaus Copernicus University in Torun, undertook the task of illustrating the history of the Evangelical Church of the Augsburg Confession in Poland during the interwar period and the effect of his work deserves praise. The issue raised by J. Kłaczkow has not been synthesized so far and is a kind of extension of the enunciations contained in the book by E. Alabrudzińska on Protestantism in interwar Poland ${ }^{1}$. The book was published, in accordance with the Author's declaration, on the occasion of the 500th anniversary of the Reformation.

Jarosław Kłaczkow did not specify the goals of his work in the introduction, so it is difficult to say whether and to what extent they have been achieved. This is partly understandable because the book - as the Author himself emphasizes - is a synthesis and as a work synthesizing the history of the Polish Evangelical-Augsburg Church it fulfils its role. Some of its fragments have already been published by the Author in the form of articles and expand upon them. In a short conclusion, J. Kłaczkow describes the issues that were emphasized in the work (without justification) and those issues which, in his opinion, deserve special attention. In my opinion, however, these are elements that should be included in the introduction to the book.

In the source base, the Author primarily used materials collected in Polish archives, such as the Archives of Modern Records in Warsaw, the Central Military Archives, state archives in Bydgoszcz, Poznań and Torun; as far as foreign sources are concerned he used Evangelisches

$1 \quad$ E. Alabrudzińska, Protestantyzm w Polsce w latach 1918-1939, Toruń 2004. 
Zentralarchiv Berlin. The latter was probably dictated by the fact that, as already mentioned, the Germans constituted the majority of the followers of the Evangelical-Augsburg Church in Poland at that time. Ironically, the 1939 Germans destroyed most of the files of the Evangelical-Augsburg Consistory (p. 12) during the September campaign; hence, J. Kłaczkow used only a few remaining materials. He also readily used a dozen or so evangelical periodicals published in Poland, such as 'Głos Ewangelicki' or 'Przegląd Ewangelicki'. They are complemented by well-selected studies, including those published in German, although the memories listed in the bibliographic record should, in my opinion, be separated from them and included among the sources. The Author probably did not do this because there are very few of them.

The work is divided into six main chapters. The first chapter presents the statistics related to the number of Lutherans in Poland and describes the administrative structure of their community. The second chapter describes the policy pursued by the Church in question and its general functioning in Poland, i.e. the attitude to the independence of Poland, including some of its regions on annexed territories (the case of Cieszyn Silesia), the impact on education and the legal foundations of the Evangelical Church of the Augsburg Confession. Chapter three - the most interesting in my opinion - focuses on the relations between the Evangelical-Augsburg Church and the Polish state authorities. Interesting threads touched upon therein also refer to Józef Piłsudski's relationship with Lutheran Church and the attitude of the said Church to the totalitarianism developing at that time in our western neighbors. The fourth chapter describes the Evangelical press in the Second Polish Republic and discusses the periodicals that appeared at that time. In chapter five the confirmation, education, and student life of young Polish Lutherans was presented. The last, sixth chapter is dedicated to the somewhat forgotten figure of Juliusz Bursche, the head of the Evangelical-Augsburg Church in Poland and the most influential person from the local religious community in the political field. He is quite controversial in German circles, due to the polonizing efforts of the Lutheran followers. Arrested by the Germans, he died after his imprisonment in KL Sachsenhausen, the same tragic fate was shared by the members of his family, on whom Himmler passed a death sentence.

In his book the Author deals with many interesting issues, rarely taken up in Polish historiography, such as, for example, Protestant youth organizations, including student ones. It often touches upon the situation of evangelical churches in particular regions of Poland, which also deserves praise, as their fate and principles of further functioning depended on the geopolitical situation. He also referred to the background behind the 
enacting of the law (in fact it was a presidential decree with the force of law) on the 'Relations of States to the Evangelical Church of the Augsburg Confession' of 1936. The coming into effect of this act was sabotaged by German pastors, but the las finally passed and was in force in Poland until 1994 (p. 97).

On pages 107-11, the Author focuses on the issue of ecumenism, but only in relation to Protestant communities. It is a pity that he did not outline their relationship with the Catholic Church, which, after all, was the largest religious group in Poland and made a huge impact on the shape of social and political life. J. Kłaczkow mentions that there were tensions in this area sometimes. For example, the issue of mixed marriages made in evangelical churches, later cancelled by Catholic courts, provoked great emotions at the meetings of evangelical organizations. For this purpose, a protest was even sent to the Polish government (p. 106).

It is worth noting that although the Polish Evangelical press in the Second Polish Republic expressed a national worldview and the editors of Evangelical periodicals were convinced nationalists, from the very beginning, in the footsteps of Protestant churches in Germany, they condemned Nazism and its degeneracy. Many critical comments about Hitler and his totalitarian rule appeared in such periodicals as 'Przegląd Ewangelicki', 'Głos Ewangelicki', and even 'Ewangelik Górnośląski' (p. 138). Hitler's anti-Christianism, although not always expressed explicitly, was well known to all Christian communities, not only Catholic. This was later reflected in the help provided to Jews during World War II, especially by the Catholic Church. Its clergymen and monks often had to pay the highest price for such acts. It is a pity that J. Kłaczkow did not refer at this point to the attitude of all Polish nationalists to Nazism or fascism, for example to the work of Krzysztof Kawalec ${ }^{2}$. Articles on this subject also appeared every now and then in National Democratic 'Przegląd Wszechpolski'3.

Chapter three deserves the title of the most interesting and the most resounding one in my opinion. The Author is as if outraged by the fact that the March Constitution gave the Catholic Church the title of the supreme one among equal denominations (p. 120). Perhaps, as J. Kłaczkow emphasizes, it was a 'strange and ambiguous legal term' ${ }^{4}$, but it referred to the Constitution of 3 May, which contained a similar regulation. Anyway,

\footnotetext{
2 K. Kawalec, Narodowa Demokracja wobec faszyzmu 1922-1939: ze studiów nad dziejami myśli politycznej obozu narodowego, Warszawa 1989.

3 See: D. Wądołowski, Hitleryzm a Kościót katolicki, 'Przegląd Wszechpolski' 1938, 26, pp. 466-467.

4 'dziwny i dwuznaczny termin prawniczy'.
} 
the Author is aware of the political influences of the Roman Catholic Church in Poland at that time (p. 119), which is why this regulation was only a formal, normative expression directly exemplifying the sociopolitical reality of the time. If it did not exist, it would still function as 'unwritten law'.

Certainly, one cannot agree with the Author's statement that Endecja (National Democratic Party) 'for the entire twenty years strove to ensure the Catholic Church and its ideology a serious position in public life ${ }^{5}$ (ibidem). To substantiate this thesis, he refers to Dmowski's brochure entitled Kościót, naród $i$ państwo, which was published after the May Coup. It was then that Dmowski removed all anti-church elements from his program and from then on promoted the catchphrase of the 'PolakKatolik', although he himself was formally an agnostic ${ }^{6}$. From the end of the 19th century until the mid-1920s National Democratic circle, especially its young generation, was often influenced by positivist slogans and was generally hostile towards religion?

The Author, however, rightly argues that the PPS (Polish Socialist Party), that Marshal Piłsudski hailed from, was clearly left-wing and evidently anticlerical, although in many respects the cooperation between the Sanacja and the Catholic Church after 1926 was admirably positive. The Catholic Church, however, was to a large extent in conflict with the Sanacja camp, which was emphasized in a special memorandum by the then Polish Primate, August Hlond, despite his generally favorable attitude towards the Marshal. Much valuable information on this subject can be found in the article by Fr. Józef Dębiński, put together in a 2008 collective work, published by the Author's home university ${ }^{8}$.

Regarding the religiousness of the Marshal, the Author states that 'for him personally, religion did not play such an important role, although he approached religious issues seriously ${ }^{\prime 9}$ (p. 146). Piłsudski's attitude to religion was generally indifferent, one might say infantile, and in this

5 'zabiegała przez całe dwudziestolecie o zapewnienie Kościołowi katolickiemu i jego ideologii poważnej pozycji w życiu publicznym'.

6 A. Wielomski, Nacjonalizm a katolicyzm, Wzajemne relacje i pojmowanie - od Piusa XII do Jana Pawła II, in: Nacjonalizmy różnych narodów. Perspektywa politologiczno-religioznawcza, eds. B. Grott, O. Grott, Kraków 2012, p. 35.

7 K. Wołek, Stosunek Demokracji Narodowej do Kościoła katolickiego przed I wojna światowa, in: Studia nad polityka polska XX wiek. Relacje państwo - Kościót, ed. M. Ryba, Lublin 2016, pp. 24-26.

8 Rev. J. Dębiński, Józef Piłsudski a Kościót katolicki w Polsce w latach 1918-1935, in: Józef Piłsudski wobec Europy i wybranych zagadnień wewnętrznych Drugiej Rzeczypospolitej (19181935). W 70 rocznicéśmierci, eds. M. Wojciechowski, Z. Karpus, Włocławek-Toruń 2007.

9 'dla niego osobiście religia nie odgrywała aż tak istotnej roli, aczkolwiek do kwestii wyznaniowych podchodził poważnie'. 
case one must agree with the above sentence of the Author. J. Kłaczkow, however, presents the unclear, behind-the-scenes matters of Marshal's close ties of with the Evangelicals, even after his return to the bosom of the Catholic Church. Perhaps it was due to his indifferentism, which helped him maintain very favorable relations also with the Jewish minority, as well as with Freemasonry. His ties with the latter were so close that he was called a 'mason without an apron' ${ }^{10}$. Many 'post-May' politicians, including prime ministers, were freemasons, which also aroused opposition from the Catholic Church ${ }^{11}$. It is a pity that J. Kłaczkow, discussing the Marshal's religious issues, did not refer to the work by Fr. Józef Warszawski ${ }^{12}$.

The publication by Jarosław Kłaczkow raises not only historical, but also religious and, partly, theological issues. The entire reviewed synthesis, despite the occasional minor drawbacks, should be assessed positively. The book reads lightly and pleasantly. Perhaps, from the Catholic point of view, the presented issues would be framed slightly differently or would be more widely exposed; from the point of view of the Catholic Church, for example, there are no 'Protestant Churches' - they are rather 'Christian communities', as once clearly pointed out Pope Benedict XVII'. The reviewed publication is probably a result of the Author's hard and long work, as it partially consists of his publications that appeared years ago. Those interested in the subject matter can be referred to another book by J. Kłaczkow, devoted to the history of the Evangelical Church of the Augsburg Confession in Poland in the years 1945-1975 ${ }^{14}$.

(translated by LINGUA LAB)

\section{REFERENCES}

\section{Studies}

Alabrudzińska E., Protestantyzm w Polsce w latach 1918-1939, Toruń 2004.

Dębiński J., Józef Piłsudski a Kościót katolicki w Polsce w latach 1918-1935, in: Józef Piłsudski wobec Europy i wybranych zagadnień wewnętrznych Drugiej Rzeczypospolitej (1918-1935). W 70 rocznicę śmierci, eds. M. Wojciechowski, Z. Karpus, Włocławek-Toruń 2007.

10 'masonem bez fartuszka'. R. Radosik, Stereotyp masona w twórczości Skamandrytów, 'Ars Regia. Czasopismo Poświęcone Myśli i Historii Wolnomularstwa' 2010, 12, 19, p. 136.

11 A. Zwoliński, Polskie ścieżki masonerii, Kraków 2014, p. 111.

12 Rev. J. Warszawski, Piłsudski a religia, Warszawa 1999. See also: W. Wysocki, Józefa Pitsudskiego wizerunek religijny, Warszawa 2016.

13 https://www.ekumenizm.pl/ekumenizm/na-swiecie/co-benedykt-xvi-powiedzial mysli-o-ekumenizmie/ [accessed on: 8 VIII 2019]. In the review, I consistently use the term 'churches', because this is the terminology used by the Author of the book.

14 J. Kłaczkow, Kościót Ewangelicko-Augsburski w Polsce w latach 1945-1975, Toruń 2010. 
Kawalec K., Narodowa Demokracja wobec faszyzmu 1922-1939: ze studiów nad dziejami myśli politycznej obozu narodowego, Warszawa 1989.

Kłaczkow J., Kościót Ewangelicko-Augsburski w Polsce w latach 1945-1975, Toruń 2010.

Radosik R., Stereotyp masona w twórczości Skamandrytów, 'Ars Regia. Czasopismo Poświęcone Myśli i Historii Wolnomularstwa' 2010, 12, 19.

Warszawski J., Pitsudski a religia, Warszawa 1999.

Wądołowski D., Hitleryzm a Kościół katolicki, ‘Przegląd Wszechpolski’ 1938, 26.

Wielomski A., Nacjonalizm a katolicyzm, Wzajemne relacje i pojmowanie - od Piusa XII do Jana Pawła II, in: Nacjonalizmy różnych narodów. Perspektywa politologiczno-religioznawcza, eds. B. Grott, O. Grott, Kraków 2012.

Wołek K., Stosunek Demokracji Narodowej do Kościoła katolickiego przed I wojna światowa, in: Studia nad polityka polska XX wiek. Relacje państwo - Kościót, ed. M. Ryba, Lublin 2016.

Wysocki W., Józefa Piłsudskiego wizerunek religijny, Warszawa 2016.

Zwoliński A., Polskie ścieżki masonerii, Kraków 2014.

\section{Web sources}

https://www.ekumenizm.pl/ekumenizm/na-swiecie/co-benedykt-xvi-powiedzialmysli-o-ekumenizmie/ [accessed on: 8 VIII 2019].

Przemysław Sołga

(Pedagogical University of Krakow) https://orcid.org/0000-0002-0670-8857

E-mail: przemyslaw.solga@gmail.com

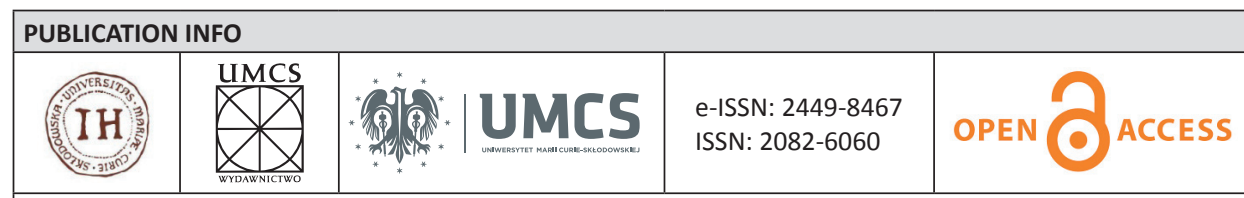

THE AUTHOR'S ADDRESS: Przemysław Sołga, the Institute of History \& Archival Studies of the Pedagogical University of Krakow, 2 Podchorążych Street, Kraków 30-084, Poland

SOURCE OF FUNDING: Financed from the author's own funds

\begin{tabular}{|l|l|l|}
\hline $\begin{array}{l}\text { SUBMITTED: } \\
\text { 2019.10.07 }\end{array}$ & $\begin{array}{l}\text { ACCEPTED: } \\
2020.11 .17\end{array}$ & $\begin{array}{l}\text { PUBLISHED ONLINE: } \\
2020.12 .21\end{array}$ \\
\hline $\begin{array}{l}\text { WEBSITE OF THE JOURNAL: } \\
\text { https://journals.umcs.pl/rh }\end{array}$ & $\begin{array}{l}\text { EDITORIAL } \\
\text { COMMITTEE E-mail: } \\
\text { reshistorica@umcs.pl }\end{array}$ & Crossref dol \\
\hline
\end{tabular}

